\title{
Novel insights into the genetic basis of buffalo reproductive performance
}

\author{
Jun Li ${ }^{1,2}$, Jiajia Liu', Giuseppe Campanile, Graham Plastow ${ }^{4}$, Chunyan Zhang ${ }^{4}$, Zhiquan Wang ${ }^{4}$, \\ Martino Cassandro ${ }^{5}$, Bianca Gasparrini ${ }^{3}$, Angela Salzano ${ }^{3}$, Guohua Hua', Aixin Liang ${ }^{1 *}$ and Liguo Yang ${ }^{1 *}$
}

\begin{abstract}
Background: Fertility is a complex trait that has a major impact on the development of the buffalo industry. Genome-wide association study (GWAS) has increased the ability to detect genes influencing complex traits, and many important genes related to reproductive traits have been identified in ruminants. However, reproductive traits are influenced by many factors. The development of the follicle is one of the most important internal processes affecting fertility. Genes found by GWAS to be associated with follicular development may directly affect fertility. The present study combined GWAS and RNA-seq of follicular granulosa cells to identify important genes which may affect fertility in the buffalo.

Results: The 90 K Affymetrix Axiom Buffalo SNP Array was used to identify the SNPs, genomic regions, and genes that were associated with reproductive traits. A total of 40 suggestive loci (related to 28 genes) were identified to be associated with six reproductive traits (first, second and third calving age, calving interval, the number of services per conception and open days). Interestingly, the mRNA expressions of 25 of these genes were also observed in buffalo follicular granulosa cells. The IGFBP7 gene showed high level of expression during whole antral follicle growth. The knockdown of IGFBP7 in buffalo granulosa cells promoted cell apoptosis and hindered cell proliferation, and increased the production of progesterone and estradiol. Furthermore, a notable signal was detected at 2.3-2.7 Mb on the equivalent of bovine chromosome 5 associated with age at second calving, calving interval, and open days.
\end{abstract}

Conclusions: The genes associated with buffalo reproductive traits in this study may have effect on fertility by regulating of follicular growth. These results may have important implications for improving buffalo breeding programs through application of genomic information.

Keywords: Follicle, GWAS, Gene expression, IGFBP7, Reproduction

\section{Background}

Buffalo is a mono-ovular species, during whose oestrus period, generally only one follicle matures and ovulates resulting in a major reduction in fertility, which restricts the development of the buffalo industry. Reproductive traits are quantitative traits influenced by many factors. With the application of genome-wide association studies (GWAS) for mapping genes for complex traits in domestic animals (e.g., pig, cattle and sheep), many important genes related to quantitative traits have been identified [1, 2]. However, only two GWAS have been performed for buffalo reproductive traits so far $[3,4]$.

\footnotetext{
*Correspondence: lax.pipi@mail.hzau.edu.cn; liguoyang2006@163.com ${ }^{1}$ College of Animal Science and Technology, Huazhong Agricultural University, Wuhan, Hubei, China

Full list of author information is available at the end of the article
}

In our previous study, nine significant $(P<0.001)$ SNPs associated with buffalo reproductive traits were identified by using the BovineSNP50 BeadChip from cattle [3]. With a significance threshold of $P<10^{-4}, 12$ markers associated with four reproductive traits (age at first calving, calving interval, number of services per conception, and open days) of Murrah buffalo were detected by using a buffalo SNP chip array (Axiom ${ }^{\bullet}$ Buffalo Genotyping Array $90 \mathrm{~K}$ Affymetrix) [4]. Mutations detected by GWAS were generally located in intergenic regions [5]. Whether these mutations affect target traits through specific pathways are unknown.

A thorough understanding of the biology of reproductive traits will be beneficial to the further development of buffalo breeding programs. Genetic variations are expected to alter gene expression leading to changes in the

(c) The Author(s). 2018 Open Access This article is distributed under the terms of the Creative Commons Attribution 4.0 International License (http://creativecommons.org/licenses/by/4.0/), which permits unrestricted use, distribution, and 
abundance of one or multiple proteins in turn affecting the phenotype of traits [6,7]. Next generation sequencing (NGS) technology has been developed for the analysis of mRNA expression, and it has also been used for determining candidate genes which regulate reproductive performance of cattle [8] and buffalo [9]. Integrating GWAS and RNA-seq to detect important genes associated with target traits has been reported to provide new insight into the identity of causal genes and mutations and how they may influence the trait [10-13]. Up to now no reports related to buffalo reproductive traits with the integrated techniques have been available.

The manipulation of reproduction often relies on the regulation of follicle development during oestrous cycles. The process of folliculogenesis includes primordial follicle recruitment, followed by granulosa cell (GC) proliferation, and differentiation, and antral or preovulatory follicle formation $[14,15]$. Every step of the folliculogenesis process is crucial for efficient fertility. In cattle, ovulation of large prolonged dominant follicles was reported to have resulted in a decrease in fertility [16], which was thought to be attributed to a reduction in fertilization rates or early embryo survival. Furthermore, oogenesis and folliculogenesis are inextricably linked, and the growth of oocytes are interdependent on that of the granulosa cells in the follicle [17]. The genes related to follicle development are therefore speculated to be important genes affecting the reproductive performance.

The $90 \mathrm{~K}$ commercial buffalo SNP chip, as an appropriate available tool [18], was applied to genotype 462 Italian Mediterranean buffaloes with 1424 lactations in this study. We therefore integrated GWAS results with our previous RNA-seq results [9] to identify the key genes affecting follicular development of buffalo. Our results lay the foundation for the understanding the genetic mechanism of buffalo reproduction.

\section{Results}

\section{Genome-wide association study}

Forty top suggestive $\left(P<10^{-4}\right)$ markers were observed (Table 1), 3 to 10 of which, were associated with the different traits. According to the cattle genome reference (Bos taurus UMD3.1 assembly), the SNPs of AX-85092311, AX-85128429, and AX-85136537 were found within genes (TBCB, NDUFS2 and TRHDE). The remainders were aligned to intergenic regions (SESN3, GPATCH4, IQGAP3, COL23A1, CADM2, FSTL4, BRINP2, KCNMA1, MEF2D, IGFBP7, NUFIP2, DIAPH3, CDH10, THRB, KYNU, CSGALNACT1, ZNF503, TRHDE, HYAL4, KRR1, MTPN, PELI2, SOX21, GMDS, PRDM5 and LMO4), which were spread over 17 chromosomes. Interestingly, the SNP of AX-85178307 was associated with TCA and SCA, and another SNP AX-85127260 was associated with TCA and $\mathrm{CI}$, which is in line with the correlations observed between traits.
Table 1 Genes near to the most suggestive SNPs $(P<0.0001)$ for six reproductive traits

\begin{tabular}{|c|c|c|c|c|c|}
\hline Traits & SNP ID & Chr & Position(bp) & Within Gene & Nearst Gene \\
\hline \multirow[t]{3}{*}{ FCA } & AX-85104022 & 15 & $15,493,494$ & - & SESN3 \\
\hline & AX-85147160 & 15 & $15,464,584$ & - & SESN3 \\
\hline & AX-85066093 & 3 & $14,263,986$ & - & GPATCH4 \\
\hline \multirow[t]{5}{*}{ SCA } & AX-85115405 & 3 & $14,360,109$ & - & IQGAP3 \\
\hline & AX-85098201 & 7 & $40,737,269$ & - & COL23A1 \\
\hline & AX-85077363 & 1 & $31,982,649$ & - & CADM2 \\
\hline & AX-85041155 & 1 & $31,452,080$ & - & CADM2 \\
\hline & AX-85178307 & 7 & $46,586,723$ & - & FSTL4 \\
\hline \multirow[t]{10}{*}{ TCA } & AX-85178307 & 7 & $46,586,723$ & - & FSTL4 \\
\hline & AX-85097354 & 16 & $59,785,310$ & - & BRINP2 \\
\hline & AX-85109602 & 28 & $32,271,813$ & - & KCNMA1 \\
\hline & AX-85092311 & 18 & $46,969,939$ & $T B C B$ & - \\
\hline & AX-85115405 & 3 & $14,360,109$ & - & MEF2D \\
\hline & AX-85160204 & 6 & $74,395,035$ & - & IGFBP7 \\
\hline & AX-85115163 & 19 & $21,212,867$ & - & NUFIP2 \\
\hline & AX-85128429 & 3 & $8,311,409$ & NDUFS2 & - \\
\hline & $A X-85127260$ & 28 & $32,296,913$ & - & KCNMA1 \\
\hline & AX-85060416 & 12 & $3,071,256$ & - & DIAPH3 \\
\hline \multirow[t]{7}{*}{ NSC } & AX-85122558 & 2 & $54,971,771$ & - & KYNU \\
\hline & AX-85080363 & 20 & $48,102,049$ & - & $\mathrm{CDH} 10$ \\
\hline & AX-85149823 & 27 & $41,131,140$ & - & THRB \\
\hline & AX-85080722 & 2 & $55,117,009$ & - & KYNU \\
\hline & AX-85118378 & 27 & $37,743,905$ & - & CSGALNACT1 \\
\hline & AX-85069249 & 28 & $32,035,318$ & - & ZNF503 \\
\hline & AX-85069116 & 20 & $47,969,440$ & - & $\mathrm{CDH} 10$ \\
\hline \multirow[t]{9}{*}{ OD } & AX-85166811 & 5 & $2,459,053$ & - & TRHDE \\
\hline & AX-85107057 & 5 & $2,430,266$ & - & TRHDE \\
\hline & AX-85107924 & 5 & $2,493,145$ & - & TRHDE \\
\hline & AX-85078259 & 5 & $2,531,719$ & - & TRHDE \\
\hline & AX-85136537 & 5 & $2,378,071$ & TRHDE & - \\
\hline & AX-85092056 & 5 & $2,670,570$ & - & TRHDE \\
\hline & AX-85058327 & 4 & $89,251,931$ & - & HYAL4 \\
\hline & AX-85129886 & 5 & $5,220,162$ & - & KRR1 \\
\hline & AX-85080072 & 4 & $100,837,591$ & - & MTPN \\
\hline \multirow[t]{6}{*}{$\mathrm{Cl}$} & AX-85097797 & 10 & $69,031,255$ & - & PELI2 \\
\hline & AX-85056150 & 12 & $70,335,740$ & - & $50 \times 21$ \\
\hline & AX-85091977 & 23 & $51,462,571$ & - & GMDS \\
\hline & AX-85082041 & 6 & $5,090,318$ & - & PRDM5 \\
\hline & AX-85127260 & 28 & $32,296,913$ & - & KCNMA1 \\
\hline & AX-85154020 & 3 & $56,690,373$ & - & LMO4 \\
\hline
\end{tabular}

FCA Age at first calving, SCA Age at second calving, TCA Age at third calving, Cl Calving interval, NSC The number of artificial insemination, OD The open days. Chr and Position were obtained based on the cattle genome (Bos taurus UMD3.1 assembly) 
Linkage disequilibrium and haplotype associations

A particularly significant genomic region located at the equivalent 2.3-2.7 $\mathrm{Mb}$ of BTA5 (Bos taurus UMD 3.1 assembly), including six suggestive $\left(P<10^{-4}\right)$ SNPs, was identified to be associated with OD trait based on the GWAS results (Fig. 1). LD analysis indicated that a block (about $292 \mathrm{~kb}$ ) was related to the above region (Fig. 2). Nine markers were in this block and they were in high $\mathrm{LD}$, and most of them located in the TRHDE gene.

Four common haplotypes (CCGCATTAT, TTATGCCGC, TTATGCTAC, and CCGCACTAT) were inferred, and ten haplotype blocks were identified based on these four haplotypes. The analysis of relationship between haplotype blocks and buffalo reproductive traits revealed that haplotype blocks had significant effects on SCA $(P<0.05), C I \quad(P<0.001)$ and OD $(P=0.001)$. The multiple comparative analyses of the relationship between haplotype blocks and the three traits were shown in Additional file 1: Table S1, S2, and S3. The haplotype block (CCGCACTAT, TTATGCTAC) was associated with less second calving days, the haplotype block (CCGCATTAT, CCGCACTAT) was associated with the shortest calving interval, and the haplotype block (CCGCACTAT, CCGCACTAT) was associated with least open days.

\section{Potential genes identified by combining RNA-seq with GWAS}

According to the RNA-seq results, 25 of 28 genes identified by GWAS were found to be expressed in buffalo follicular GCs (Table 2). The highest expression was found in IGFBP7 during whole follicle growth in GCs, followed by NDUFS2, TBCB, MTPN, and GMDS. It is worth mentioning that the expression of the CSGALNACT1 gene decreased gradually with the increase in follicular diameter, and was differentially expressed (FDR $<0.05)$ between small and large follicles $(<5 \mathrm{~mm}$ and $>8 \mathrm{~mm}$ in diameter).
Four genes (IGFBP7, CSGALNACT, MTPN, and GPATCH) with high expression level according to RNA-seq were selected for q-PCR validation. The expression patterns of these selected genes at four stages obtained by q-PCR were basically consistent with RPKM values obtained by RNA-seq (Fig. 3). IGFBP7 was highly expressed during follicular development, so we chose this gene for subsequent functional verification.

\section{Knockdown of IGFBP7 affects cell growth}

To investigate whether IGFBP7 plays a role in the development of buffalo GCs, two recombinant RNAi vectors were constructed. Both RNAi vectors were effective in knocking down IGFBP7 in buffalo GCs. The ssRNAi-1 vector had a better effect (98\%) compared with ssRNAi-2 (Fig. 4b). Therefore, recombinant ssRNAi-1 vector was used for subsequent experiments.

The knockdown of IGFBP7 led to the arrest of the cell cycle and the increase in the proportion of early apoptotic cells. The percentage of GCs in G2 phase was significantly $(P<0.05)$ increased and the portions of GCs in the $\mathrm{G} 1$ and $\mathrm{S}$ phase were decreased $(P<0.05)$ (Fig. $4 \mathrm{~d})$. The IGFBP7 silencing resulted in the significant increase in the number of apoptotic cells, compared with that of the control vector $(7.5 \pm 3.2$ vs $2.9 \pm 0.5, P=0.003)$ (Fig. 4e). The results of apoptosis were also confirmed by detecting mRNA expression of $B C L 2, B A X$, and CASPASE3 after IGFBP7 knockdown (Fig. 5). The knockdown of IGFBP7 also suppressed buffalo GCs proliferation. The absorbance at $450 \mathrm{~nm}$ in ssRNAi transfected cells was higher than that of control group (Fig. 4c).

\section{Knockdown of IGFBP7 increased basal progesterone and E2 production}

The production of progesterone and E2 increased $(P<$ 0.05 ) by knockdown of IGFBP7 in buffalo GCs cultured

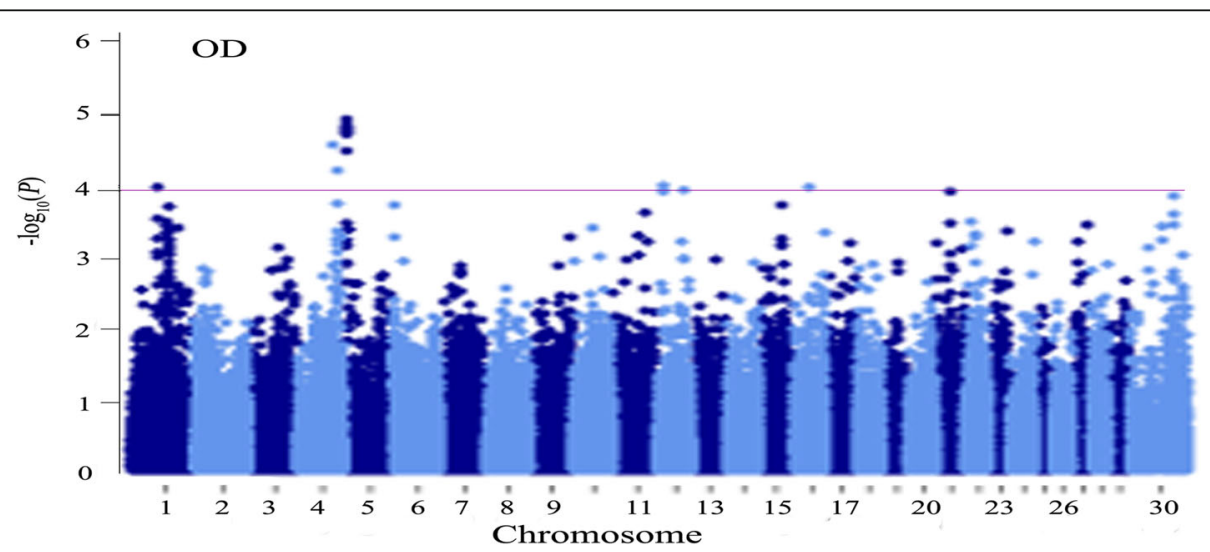

Fig. 1 Manhattan plot for GWAS of open days in buffalo. OD, open days; x-axis, physical positions of SNPs by chromosome based on Bos taurus UMD3.1 genome assembly; $y$-axis, - $\log 10$ ( $P$-values) 


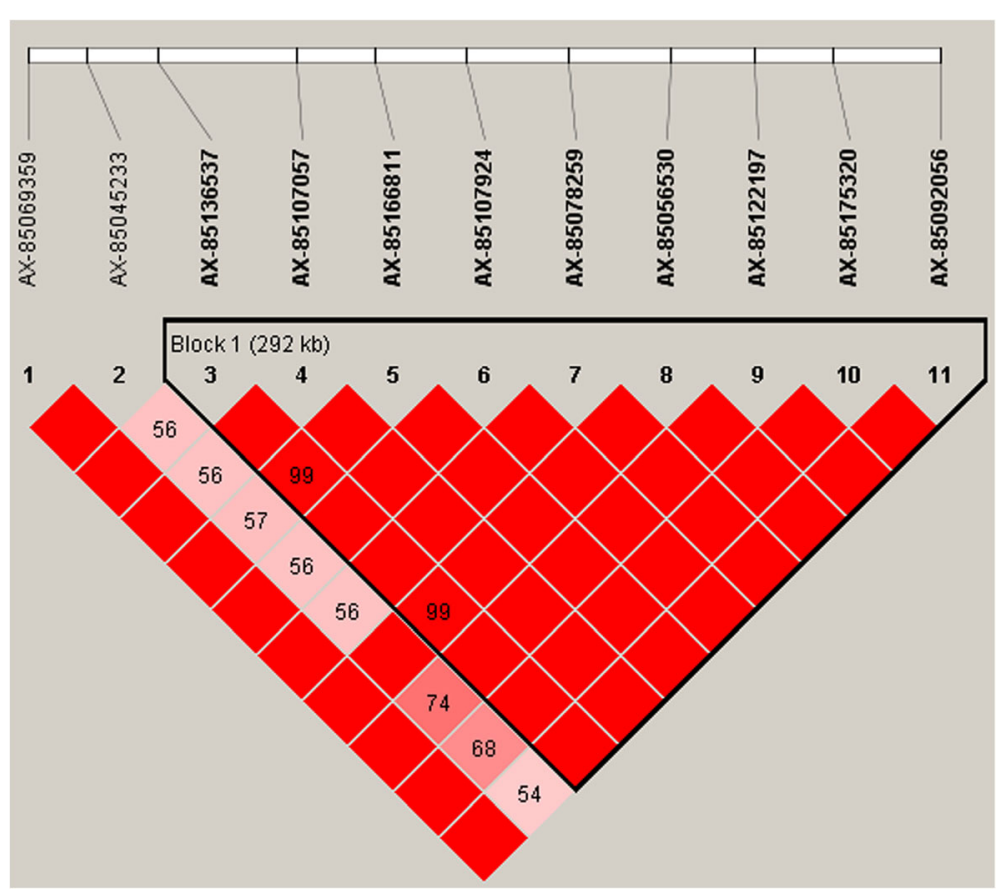

Fig. 2 Linkage disequilibrium pattern for 11 SNPS, which have significant effects on OD by GWAS between 2 - 3Mbp on BTA5. Linkage disequilibrium block is presented in a triangle box based on LD (squared correlation coefficient, r2)

for $48 \mathrm{~h}$ after transfection (Fig. 6a). Furthermore, IGFBP7 silencing increased the mRNA expression of STAR and decreased the mRNA expression of CYP11A1 while no significant change in mRNA expression of CYP21A2 was observed (Fig. 6b).

\section{Discussion}

In a previous study, 12 significant $\left(P<10^{-4}\right)$ SNPs associated with four reproductive traits were identified by GWAS in Murrah buffalo [4]. Nonetheless, these 12 significantly associated SNPs were not detected in the present study. Furthermore, a recent study showed more than 150 SNPs were associated with indicator traits of sexual precocity [19], however, none of them are identified in this study. Many reports indicated that GWAS has some limitations $[20,21]$, therefore, the functional verification analysis of significant SNPs detected by GWAS remains to be conducted. In a previous study, integrating sequence-based GWAS and RNA-seq provided novel insights into the genetic basis of mastitis and milk production in dairy cattle [10]. In the present study, we used GWAS to detect key genes associated with buffalo reproductive traits, and the results of RNA-seq were used to explore the changes in the expression of these key genes during the development of follicles. The expression of 25 out of 28 genes associated with buffalo reproductive traits was also detected in buffalo follicular GCs by RNA-seq, indicating that these genes may have affected the fertility by being directly through the regulation of buffalo follicle growth.
Hormones play an essential role in animal reproductive performance, and hormones and antibiotics have been applied as treatments in animal reproduction studies [22]. In the present study, five notable genes related to hormonal regulation were identified: TRHDE [23] for thyrotropin, KCNMA1 [24], TBCB [25] and CDH10 [26] for prostrate hormones, and THRB [27] for thyroid hormones. Thyroid dysfunction is associated with anovulation, abortion, and infertility in women and experimental animals [28]. Prostaglandin concentration is abnormally high in human ejaculates, and the prostate has specific dependence on androgen stimulation [29]. Thyroid hormones play a key role in seasonal cycles of body weight and reproduction [30]. Coincidentally, buffalo is also a seasonal estrus species. Furthermore, the mutation of THRB was reported to be significantly associated with thyroid hormone resistance (THR) [27]. KCNMA1 gene can enhance erectile strength and sexual behavior [31]. TRHDE encoding a thyrotropin releasing enzyme was reported to be associated with a variety of phenotypes including growth traits in Ujumqin sheep [23], the adaptation of goats to hot arid environments [32] and rheumatoid arthritis [33] in GWAS studies. According to the RNA-seq results, the expression of these hormone-related genes is low in buffalo granulosa cells, but we cannot ignore the impact of these genes because low levels of hormone may be highly effective in the regulation of follicle growth [34]. It is reasonable to assume that genes involved in hormonal regulation could be 
Table 2 The expression level of genes associated with buffalo reproduction traits identified by GWAS during four stages of buffalo follicle growth

\begin{tabular}{|c|c|c|c|c|c|}
\hline \multirow[t]{2}{*}{ Gene } & \multirow{2}{*}{$\begin{array}{l}\text { Length } \\
\text { (bp) }\end{array}$} & \multicolumn{4}{|l|}{$\mathrm{RPKM}^{*}$} \\
\hline & & $<5 \mathrm{~mm}$ & $5 \sim 8 \mathrm{~mm}$ & $8 \sim 12 \mathrm{~mm}$ & $>12 \mathrm{~mm}$ \\
\hline IGFBP7 & 1107 & 723.49 & 840.17 & 965.37 & 883.67 \\
\hline NDUFS2 & 1601 & 215.46 & 254.71 & 317.72 & 322.20 \\
\hline$T B C B$ & 994 & 76.32 & 75.14 & 81.12 & 93.92 \\
\hline MTPN & 2844 & 28.63 & 67.29 & 40.74 & 15.93 \\
\hline GMDS & 1845 & 27.68 & 23.66 & 36.08 & 33.39 \\
\hline ZNF503 & 3514 & 21.09 & 20.43 & 25.47 & 15.84 \\
\hline LMO4 & 5219 & 15.44 & 31.11 & 35.43 & 23.79 \\
\hline GPATCH4 & 1830 & 10.96 & 8.31 & 8.36 & 9.72 \\
\hline KRR1 & 1258 & 7.67 & 20.06 & 9.86 & 4.39 \\
\hline MEF2D & 5716 & 7.62 & 10.25 & 10.50 & 11.03 \\
\hline DIAPH3 & 4580 & 7.57 & 10.44 & 6.95 & 3.13 \\
\hline NUFIP2 & 3406 & 7.41 & 12.83 & 6.21 & 4.13 \\
\hline KYNU & 2273 & 4.20 & 4.49 & 7.27 & 4.51 \\
\hline CSGALNACT1 $1^{\#}$ & 3199 & $3.53^{\mathrm{a}}$ & $0.87^{\mathrm{ab}}$ & $0.42^{\mathrm{b}}$ & $0.37^{\mathrm{b}}$ \\
\hline IQGAP3 & 5860 & 3.51 & 4.93 & 3.85 & 1.71 \\
\hline PRDM5 & 6373 & 3.38 & 3.92 & 2.40 & 1.66 \\
\hline PELI2 & 5697 & 3.23 & 3.79 & 3.61 & 1.42 \\
\hline SESN3 & 7235 & 2.14 & 5.73 & 2.46 & 1.42 \\
\hline THRB & 6346 & 1.89 & 1.65 & 2.55 & 2.12 \\
\hline CADM2 & 3342 & 0.03 & 0.17 & 0.04 & - \\
\hline FSTL4 & 8110 & 0.03 & 0.03 & 0.07 & 0.12 \\
\hline KCNMA1 & 2401 & 0.03 & 0.06 & - & - \\
\hline COL23A1 & 2333 & - & - & 0.04 & 0.03 \\
\hline $50 \times 21$ & 3417 & - & 0.02 & - & - \\
\hline $\mathrm{CDH} 10$ & 3174 & - & 0.09 & - & 0.07 \\
\hline
\end{tabular}

${ }^{*}$ RPKM Reads per kb per million reads. " CSGALNACT1: significanty differentially expressed gene (FDR $<0.05)$. The different superscript letters showed significant level

associated with buffalo fertility, and that these markers may have high utilization value for buffalo breeding.

Buffalo reproductive traits are controlled by polygenes, and many genes of small effects can produce synergistic effects on a pathway. Function based analysis can be used to detect the combined effects of these genes. In the present study, five important genes, NDUFS2, GMDS, KYNU, HYAL4, and CSGALNACT1, were classified into metabolic pathways. Metabolism is one of the most basic processes in the body, and plays a crucial role in ensuring the normal performance of various life activities. These genes may affect the reproductive performance of buffalo by regulating glucose, lipid, protein, and nucleic acid metabolism. Extensive information has previously been obtained about genes involved in metabolic pathways affecting animal fertility [35]. Among these genes, the CSGALNACT1 gene, which is required for normal cartilage development [36], was found to be significantly down-regulated by comparing buffalo follicles with diameter $<5 \mathrm{~mm}$ and $>8 \mathrm{~mm}$ in the present study. Based on it, we hypothesize that CSGALNACT1 gene has effect on the growth of buffalo follicles by changing the level of expression to regulate glucose metabolism.

In our previous study, CADM2 (cell adhesion molecule 2) was found to be associated with buffalo reproductive performance by using the BovineSNP50 BeadChip [3]. One SNP located at about $143 \mathrm{~kb}$ of the upstream bovine $C A D M 2$ was associated with days from first calving to conception and calving interval in days from first to second calving. In the present study, another SNP AX-85077363 located downstream of the bovine $C A D M 2$ gene was identified to be associated with SCA trait. However, the expression of CADM2 was only detected in early follicular GCs. We speculate that the two sites nearby the CADM2 gene may interact with other significant SNPs or genes to influence buffalo reproductive performance.

ZNF503, KRR1, and MTPN are other target genes associated with buffalo reproductive traits identified in this study. ZNF503, also known as Nolz-1, which promotes mammary epithelial cell proliferation and enhances cell invasion [37], plays an important role in embryogenesis [38]. KRR1 was reported to be associated with polycystic ovary syndrome (PCOS) in European cohorts [39]. MTPN plays an essential role in cell and skeletal muscle growth [40], and it is related to antigen recognition which is a key process in immune response [41]. These three genes were highly expressed in buffalo GCs with follicular diameter $5 \sim 12 \mathrm{~mm}$, suggesting that they may have participated in dominant follicle selection.

IGFBP7 shares sequence homology with follistatin [42] which is originally considered as an inhibitor of FSH secretion $[43,44]$ and plays a crucial role in folliculogenesis and ovarian function $[45,46]$. The expression of IGFBP7 was also identified in the GCs of the large antral follicles of porcine ovary [47] and bovine corpus luteum [48]. Therefore, we speculate that IGFBP7 may participate in the regulation of follicle development and ovulation. In the present study, our RNA-seq results showed that IGFBP7 is highly expressed in GCs of buffalo antral follicles. Moreover, the knockdown of IGFBP7 in buffalo GCs affected the number of apoptotic cells, cell cycles, cell proliferation, and the production of estrogen and progesterone. These observations indicate that IGFBP7 may be involved in the regulation of follicle development.

\section{Conclusions}

This is the first attempt combining GWAS and RNA-seq to explore genetic mechanism of buffalo reproductive 


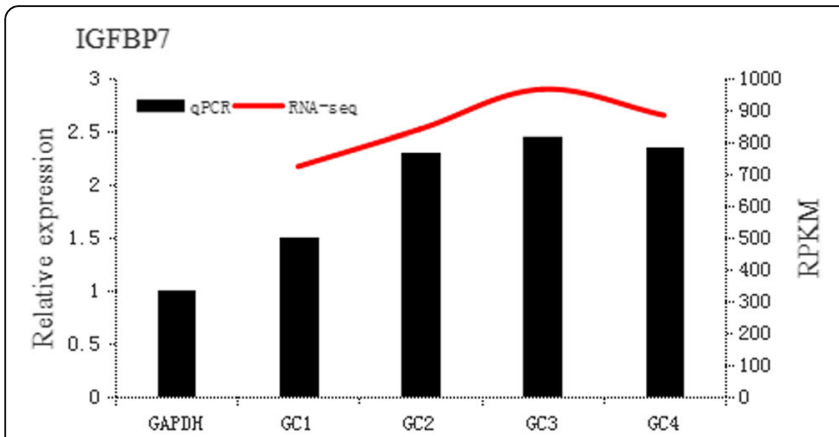

CSGALNACT
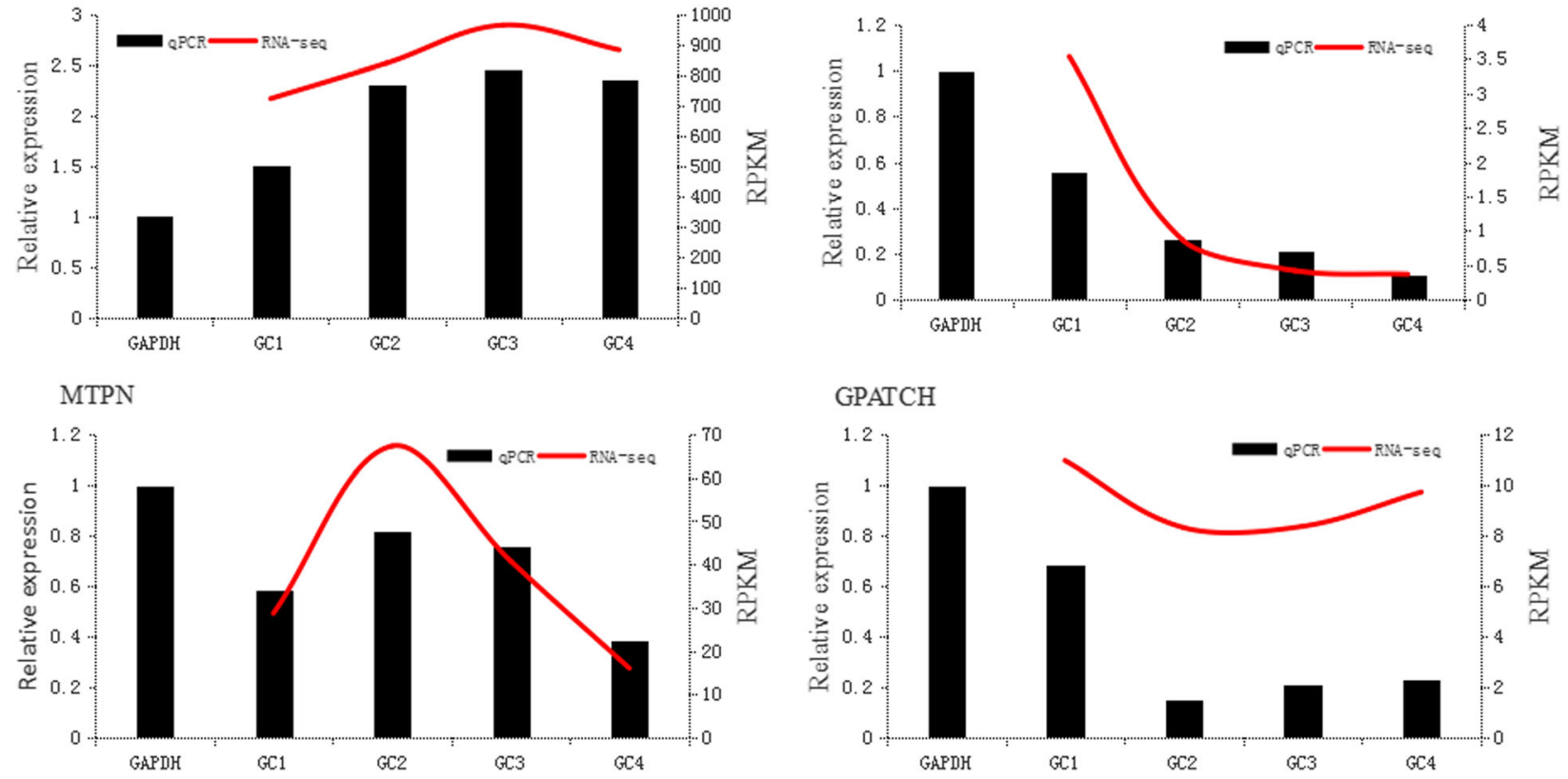

\section{GPATCH}

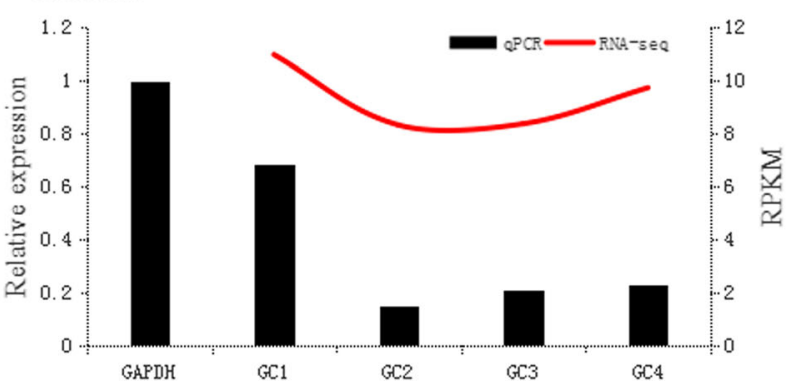

Fig. 3 Expression of selected genes mRNA in buffalo granulosa cells detected by q-PCR compared with RNA-seq

performance. A total of 25 important genes were identified to be associated with buffalo reproductive performance, and they may affect the buffalo reproductive traits through the regulation of follicle development. The study expands the knowledge of the genetic basis of buffalo fertility, and it may also benefit future research on improving buffalo breeding programs.

\section{Materials and methods}

\section{Animal and data collection}

The data and samples used for GWAS were obtained from the Italian Buffalo Breeders Association, which is responsible for the buffalo production program in Italy.

The data analysis was based on 1424 lactations of 462 Italian Mediterranean buffaloes born in 2000-2011 in four Italian farms. Six reproductive traits were examined including first calving age (FCA), second calving age (SCA), third calving age (TCA), calving interval (CI), number of services per conception (NSC), and open days (OD).

The trait FCA is defined as the days from the birth to first calving of the buffalo; SCA is defined as the days from birth to second calving of the buffalo; and the days between the third calving and the birth of buffalo is defined as TCA. The CI is defined as the days between consecutive events. The trait NSC refers to the times of artificial insemination (AI) that is required for each buffalo to conceive. The OD is defined as the days from calving to the next conception.
Data structure is important as they underpin GWAS results. The descriptive statistics of phenotypes of buffalo reproductive traits are presented in Table 3.

\section{Genotyping and quality control}

Genomic DNA was isolated from the blood leucocytes of Italian buffalo using a standard phenol-chloroform extraction protocol and the DNA was genotyped using the $90 \mathrm{~K}$ Axiom Buffalo SNP Array at Delta Genomics (Edmonton AB, Canada). Sample quality control used animal call rates $>97 \%$. For single nucleotide polymorphisms (SNPs), thresholds were set as SNPs call rates > $95 \%$, minor allele frequency (MAF) $>0.05$ and Hardy Weinberg equilibrium (HWE) test $P$-value $<10^{-6}$. Unmapped SNPs were eliminated and markers present on the Y chromosome were removed. After quality control, 62,747 SNPs and 462 buffaloes were used for subsequent analyses.

\section{Genome wide association study}

The association study was performed using a ridge regression BLUP (rrBLUP) model in both PLINK and $\mathrm{R}$ software.

$$
y=X \beta+u+e
$$

Where $\boldsymbol{y}$ is the vector of reproductive traits, $\boldsymbol{X}$ is a vector of coded SNP genotypes, which is assigned to $-1,0$, or 1 for genotypes $\mathrm{AA}, \mathrm{AB}$, and $\mathrm{BB}$, respectively. $\boldsymbol{B}$ is the SNP effect; $\boldsymbol{u}$ is the vector of the 


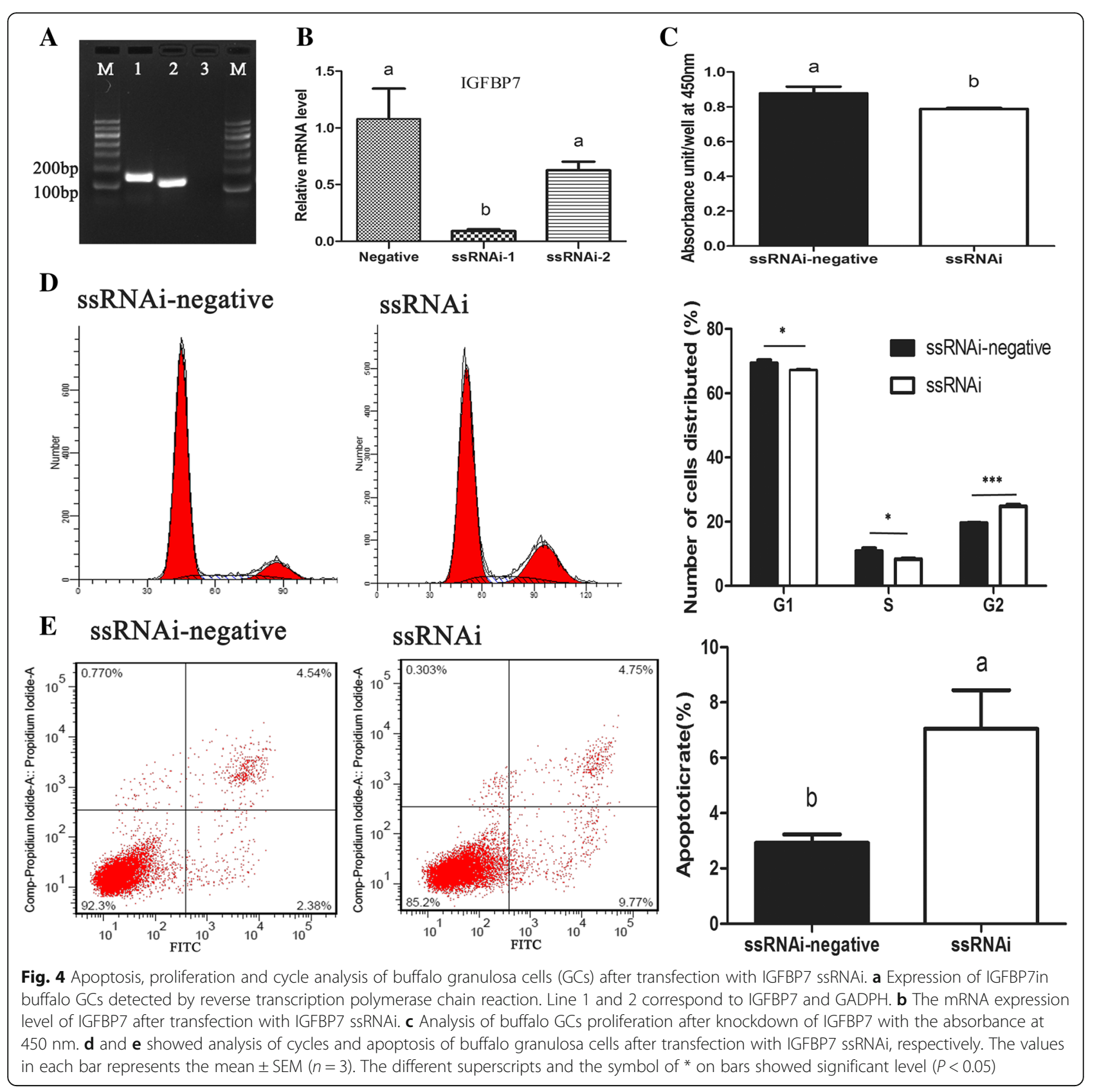

polygenic effects, and $\boldsymbol{e}$ is the vector of random residuals. $\boldsymbol{u}$ and $\boldsymbol{e}$ are assumed to be subject to the normal distribution, $\left[\boldsymbol{u} \sim\left(\mathbf{0}, \boldsymbol{K} \sigma_{u}{ }^{2}\right)\right]$ and $\left[\boldsymbol{e} \sim\left(\boldsymbol{0}, \boldsymbol{I} \sigma_{\boldsymbol{e}}{ }^{2}\right)\right]$, where $K$ is the genomic relationship matrix based on pedigree information, $\boldsymbol{\sigma}_{\boldsymbol{u}}{ }^{2}$ is the genetic variance, $I$ is an identify matrix, $\sigma_{e}{ }^{2}$ is the residual variance. The number of potential markers was too small after Bonferroni correction $\left(0.05 / 62747=7.97 \times 10^{-7}\right)$, resulting in very low statistical power. Therefore, we used suggestive $P$ value $(P<0.0001)$ as the threshold in this analysis.

\section{Haplotype analyses}

The linkage disequilibrium (LD) between markers was calculated as squared correlation coefficient $\left(\mathrm{r}^{2}\right)$ of alleles using Haploview 4.2 software. The distances of pairwise SNPs less than $500 \mathrm{~kb}$ were used to draw the LD figure. Haplotype blocks were constructed by using PHASE software, and the association between each haplotype block and six reproductive traits were estimated with Bonferroni t test in $\mathrm{R}$. We used suggestive $P$ value $(P<0.05)$ as threshold for considering candidate haplotype blocks affecting buffalo reproductive traits. 
P53
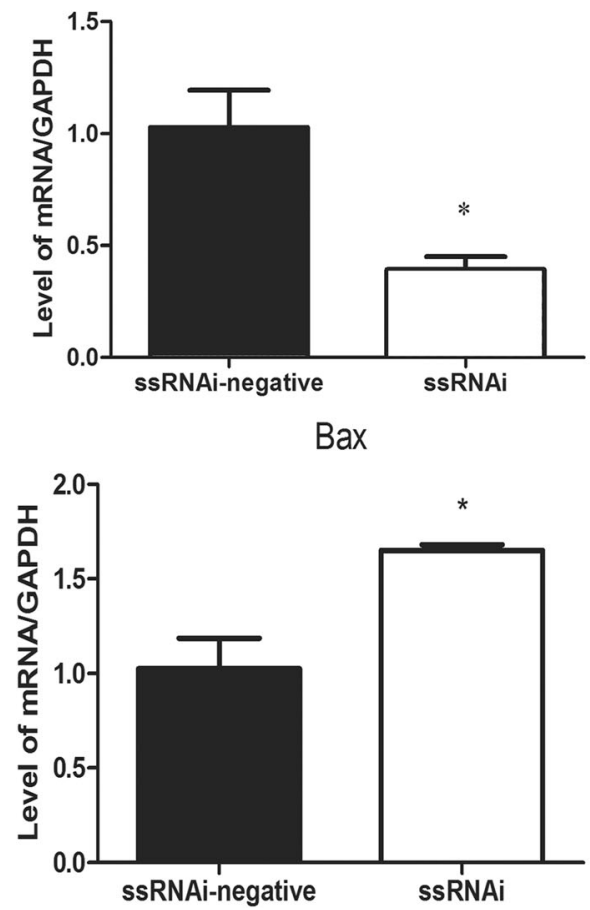

$\mathrm{Bcl}-2$
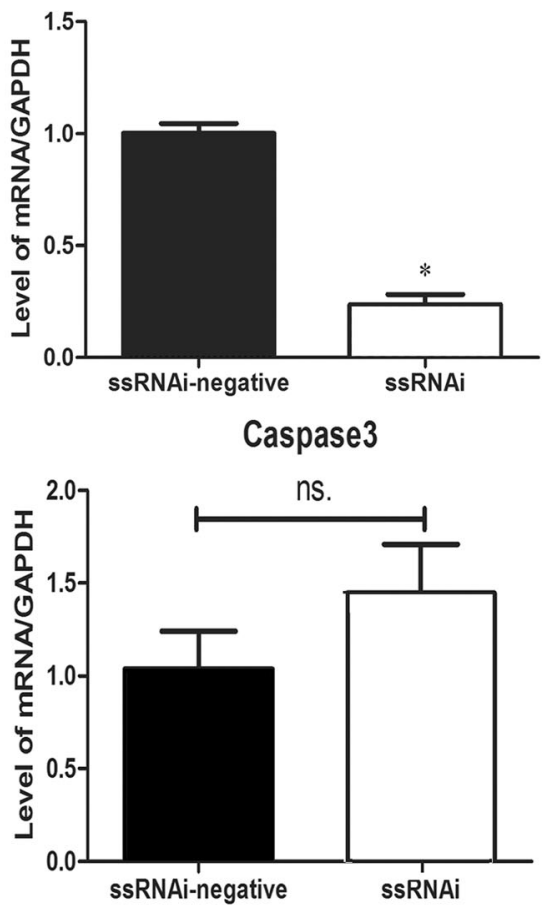

Fig. 5 Effects on different apoptotic factors after knockdown of IGFBP7 in buffalo GCs. The mRNA expression of each apoptotic related genes was presented as mean $\pm \operatorname{SEM}(n=3)$. The symbol of * on bars showed significant level $(P<0.05)$. n.s. means none-significant

\section{Identification of SNP location}

Two available buffalo genome sequences on the NCBI platform are not displayed on chromosomes and genes are not annotated (UMD CASPUR WB 2.0; https:// www.ncbi.nlm.nih.gov/assembly/GCF_000471725.1/). Cattle and buffalo have been reported to be closely related, sharing homology in chromosome banding and gene mapping $[49,50]$. It has also been confirmed that the bovine genome is a useful source of markers for buffalo genome mapping [51, 52], three available buffalo GWAS were constructed using the cattle genome reference $[4,18,53]$. In the present study, the SNP location was identified using the cattle genome sequence.

\section{Gene expression in buffalo follicular GCs}

The normal development of follicles directly affects buffalo reproductive performance. We speculated that key genes associated with reproductive performance identified by GWAS may be involved in the regulation of follicular development. Therefore, we integrated GWAS results with our previous RNA-seq results [9] to explore the expression of key genes in buffalo GCs during follicular development. The expressions of significant genes identified by GWAS were obtained by RNA-seq.
Quantitative real-time polymerase chain reaction (q-PCR) validation

Ovaries were collected from a local abattoir in Wuhan, China, from nonpregnant buffaloes. The ovaries with lutealized and large cystic follicles were detected and discarded. The largest follicles from normal ovaries were collected. Follicles were graded into 4 categories according to their diameters, namely, diameter $<5 \mathrm{~mm}, 5 \sim$ $8 \mathrm{~mm}, 8 \sim 12 \mathrm{~mm}$ and $>12 \mathrm{~mm}$, and morphological appearance was used to assess the developmental stages of the follicles. GCs were collected from the follicles after grading and each category included 10 follicles. Singlestranded cDNA was obtained from $1 \mu \mathrm{g}$ total RNA isolated from each of the groups. Primers (Additional file 1: Table S4) for q-PCR were designed using Primer Premier 5.0 software and synthesized by Sangon Biotech (Shanhai) Co. Ltd. q-PCR was performed on LightCycler 480II (Roche), using a SYBR Green-based PCR assay. A reaction system consists of a small aliquot of the cDNA (100 ng), $10 \mu \mathrm{L}$ PCR master mix (TaKaRa, Japan), $2 \mu \mathrm{L}$ of primers $(1 \mu \mathrm{L}$ of each forward and reverse primer, $10 \mathrm{pmol} / \mu \mathrm{L}$ ), and $7 \mu \mathrm{L} \mathrm{ddH}_{2} \mathrm{O}$. The $\mathrm{q}-\mathrm{PCR}$ was run as follows: $50{ }^{\circ} \mathrm{C}$ for $2 \mathrm{~min}, 95{ }^{\circ} \mathrm{C}$ for $10 \mathrm{~min}$, followed by 35 cycles of $95{ }^{\circ} \mathrm{C}$ for $30 \mathrm{~s}$, annealing temperatures for $30 \mathrm{~s}$ (the annealing temperature for each gene was shown in Additional file 1: Table S4), and $72{ }^{\circ} \mathrm{C}$ for $30 \mathrm{~s}$ in 96-well optical reaction plate. The expression levels of 


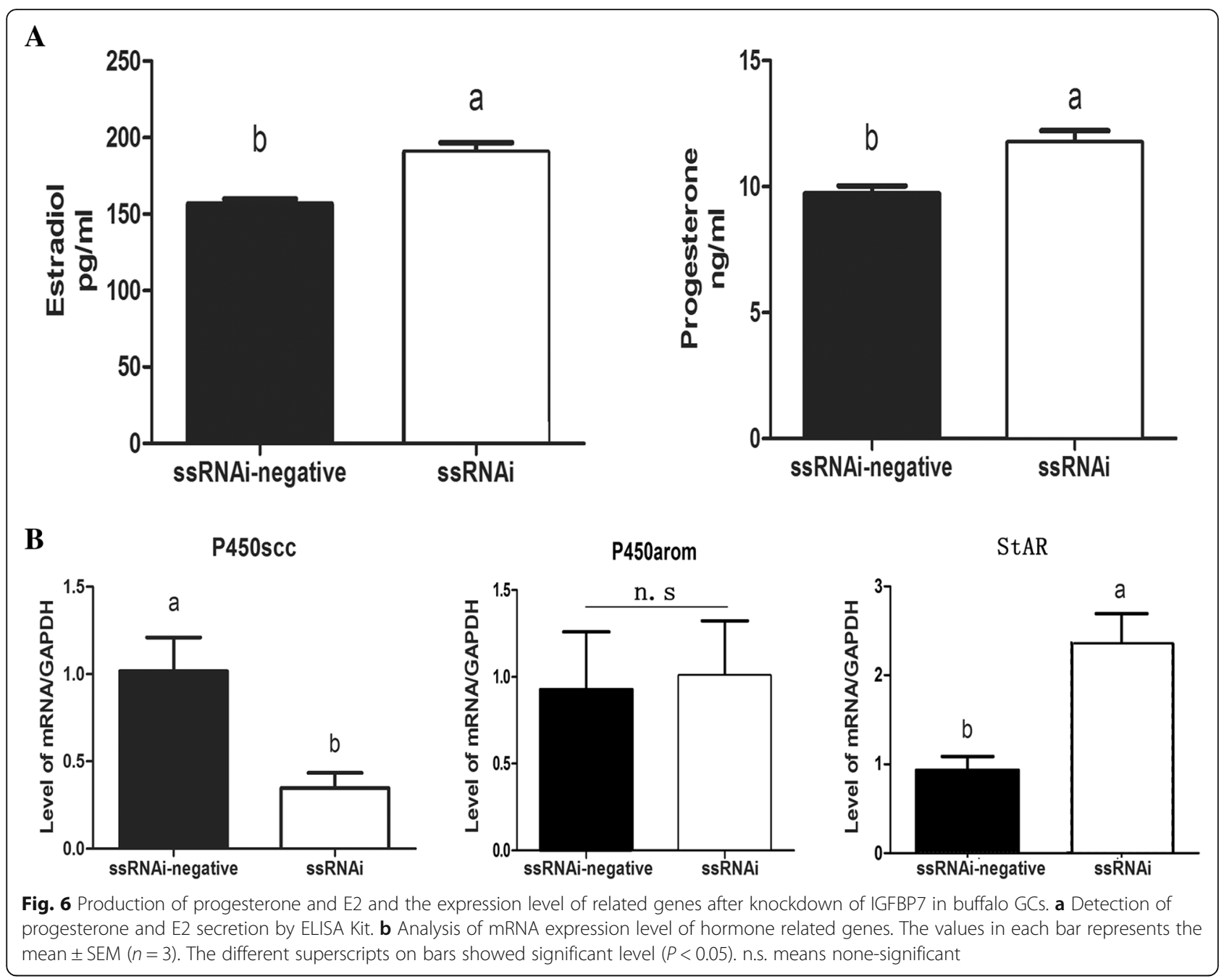

the tested genes were determined by $\mathrm{CT}$ values and the final expression for each gene was normalized against the value of GAPDH. The analyses were conducted with three biological replicates.

Functional verification by RNA interference technique.

Isolation and culture of buffalo granulosa cells were described in our previous study [54]. Two ssRNAi

Table 3 Descriptive statistics of studied reproduction traits

\begin{tabular}{llllll}
\hline Traits & Records & Mean & SD & Max & Min \\
\hline FCA & 483 & 1015.44 & 157.08 & 1769 & 574 \\
SCA & 398 & 1491.70 & 208.64 & 2317 & 797 \\
TCA & 230 & 1908.86 & 255.79 & 3071 & 1185 \\
CI & 891 & 431.55 & 75.67 & 657 & 235 \\
NSC & 1110 & 2.27 & 0.68 & 6 & 1 \\
OD & 1008 & 120.04 & 61.58 & 270 & 40 \\
\hline
\end{tabular}

SD Standard deviation, FCA Age at first calving, SCA Age at second calving, TCA Age at third calving, $\mathrm{Cl}$ Calving interval, NSC The number of artificial insemination, $O D$ Open days vectors (Additional file 1: Table S5) of insulin-like growth factor-binding protein 7 (IGFBP7) were constructed according to the coding sequence (Accession number: XM_006058372). These two plasmids and another negative control plasmid were named ssRNAi-1, ssRNAi-2, and ssRNAi-negative, respectively. The method of transfection was described in our previous study [54].

After transfection with plasmid, the mRNA expression of IGFBP7, apoptosis related genes, and hormone synthesis related genes were detected by q-PCR which was described above. AnnexinV-FITC/PI kit (KGA107, Kaiji Biotechnology Co., Ltd., Nanjing, China) was used to measure the apoptosis of GCs according to the manufacturer's protocol. Cell cycle detection was also performed using flow cytometry and the excitation wavelength was $488 \mathrm{~nm}$ according to the manufacturer's protocol of cell cycle detection kit (KGA512, Kaiji Biotechnology Co., Ltd., Nanjing, China). The analysis of cell proliferation was performed using the Cell Counting Kit (catalogue number: ck04) with absorbance wavelength being $450 \mathrm{~nm}$. 
Moreover, the cell culture medium was collected and the production of estrogen and progesterone was measured using a Bovine ELISA Kit (catalogue number: JYM0045Bo and JYM0056Bo, respectively) according to the manufacturer's instructions.

\section{Additional file}

Additional file 1: Table S1. Multiple Comparative Analysis of the relationship between Buffalo Haplotype block and SCA Trait. Table S2. Multiple Comparative Analysis of the relationship between Buffalo Haplotype block and CI Trait. Table S3. Multiple Comparative Analysis of the relationship between Buffalo Haplotype block and OD Trait. Table S4. Primers used for quantitative real-time polymerase chain reaction. Table S5. siRNA description. (DOC 64 kb)

\section{Abbreviations}

Cl: Calving interval; FCA: First calving age; GC: Granulosa cell; GWAS: Genomewide association study; HWE: Hardy - Weinberg equilibrium; LD: Linkage disequilibrium; MAF: Minor allele frequency; NGS: Next generation sequencing NSC: Number of services per conception; OD: Open days; q-PCR: Quantitative real-time polymerase chain reaction; SCA: Second calving age; SNP: Single nucleotide polymorphism; TCA: Third calving age

\section{Acknowledgements}

We thank all of the field staff and other participants in our study.

\section{Funding}

This work financially supported by the National Natural Science Foundation of China (31772602 and 31772604) and the earmarked fund for Modern Agro-industry Technology Research System (CARS-37-04B).

\section{Availability of data and materials}

The datasets used during the current study are available from the corresponding author on reasonable request.

\section{Authors' contributions}

$\mathrm{J}$ Li carried out most data analysis and gene verification experiments, and drafted the manuscript. J Liu performed the genome SNP scans and genotype analysis. GC contributed to sample preparation and collection of reproductive trait records. GP contributed to analysis of data, and assisted in revising manuscript. CZ helped to interpret the raw data and revise manuscript. ZW contributed to genotype analysis and revise manuscript. CM assisted in critical revisions of manuscript. BG contributed to collection of reproductive trait records, and assisted in critical revisions of manuscript. AS contributed to sample preparation. GH assisted in revising manuscript. AL contributed to sample preparation, experimental design and data analysis, and assisted in writing and revising manuscript. LY contributed to design the experiments and coordinate the project, and helped to draft the manuscript. All authors read and approved the final manuscript.

\section{Ethics approval}

The Scientific Ethics Committee of Huazhong Agricultural University approved the experimental design and animal treatments for the present study (permit number HZAUBU-2015-007), and all experimental protocols were conducted in accordance with the guidelines.

\section{Consent for publication}

Not applicable.

\section{Competing interests}

The authors declare that they have no competing interests.

\section{Publisher's Note}

Springer Nature remains neutral with regard to jurisdictional claims in published maps and institutional affiliations.

\section{Author details}

College of Animal Science and Technology, Huazhong Agricultural University, Wuhan, Hubei, China. ${ }^{2}$ Department of Immunology, Zunyi Medical College, Zunyi, Guizhou, China. ${ }^{3}$ Department of Veterinary Medicine and Animal Productions, University of Naples "Federico II", Naples, Italy. ${ }^{4}$ Department of Agricultural, Food \& Nutritional Science, University of Alberta, Edmonton, AB, Canada. ${ }^{5}$ Department of Agronomy, Food, Natural Resources, Animals and Environment, University of Padova, Agripolis, Legnaro, Italy.

Received: 1 March 2018 Accepted: 30 October 2018

Published online: 12 November 2018

\section{References}

1. Jiang L, Liu J, Sun D, Ma P, Ding X, Yu Y, Zhang Q. Genome wide association studies for milk production traits in Chinese Holstein population. PLoS One. 2010;5(10):e13661.

2. Goddard ME, Hayes BJ. Mapping genes for complex traits in domestic animals and their use in breeding programmes. Nat Rev Genet. 2009;10(6): 381-91.

3. Song LJ, Wu JF, Yang Guo L, Zhang SJ, Wu JJ. Investigation of transferability of BovineSNP50 BeadChip from cattle to;water buffalo for genome wide association study. Mol Biol Rep. 2013:40(2):743-50.

4. de Camargo GM, Aspilcueta-Borquis RR, Fortes MR, Porto-Neto R, Cardoso DF, Santos DJ, Lehnert SA, Reverter A, Moore SS, Tonhati H. Prospecting major genes in dairy buffaloes. BMC Genomics. 2015;16(1):872.

5. Leiserson MD, Eldridge JV, Ramachandran S, Raphael BJ. Network analysis of GWAS data. Curr Opin Genet Dev. 2013;23(6):602-10.

6. Musunuru K, Strong A, Frank-Kamenetsky M, Lee NE, Ahfeldt T, Sachs KV, Li X, Li H, Kuperwasser N, Ruda VM. From noncoding variant to phenotype via SORT1 at the 1p13 cholesterol locus. Nature. 2010;466(7307):714-9.

7. Lappalainen T, Sammeth M, Friedlander MR, t Hoen PA, Monlong J, Rivas MA, Gonzalez-Porta M, Kurbatova N, Griebel T, Ferreira PG, et al. Transcriptome and genome sequencing uncovers functional variation in humans. Nature. 2013;501(7468):506-11.

8. Sirard MA, Fournier É, Dufort I, Gilbert I, Robert C. 77 Transcriptome profiling in oocytes-embryo and granulosa cells from bovine. Reprod Fertil Dev. 2016;29(1):146-146.

9. Li J, Li Z, Liu S, Zia R, Liang A, Yang L. Transcriptome studies of granulosa cells at different stages of ovarian follicular development in buffalo. Anim Reprod Sci. 2017;187:181-92.

10. Fang L, Sahana G, Su G, Yu Y, Zhang S, Lund MS, Sã Rensen P. Integrating sequence-based GWAS and RNA-Seq provides novel insights into the genetic basis of mastitis and Milk production in dairy cattle. Sci Rep. 2017;7: 45560.

11. Calabrese GM, Mesner LD, Stains JP, Tommasini SM, Horowitz MC, Rosen CJ, Farber CR. Integrating GWAS and co-expression network data identifies causal bone mineral density genes SPTBN1 and MARK3 and an osteoblast functional module. Cell Systems. 2017;4(1):46-59.

12. Calabrese G, Bennett BJ, Orozco L, Kang HM, Eskin E, Dombret C, De Backer O, Lusis AJ, Farber CR. Systems genetic analysis of osteoblast-lineage cells. PLoS Genet. 2012;8(12):e1003150.

13. Li J, Liu X, Yang J, Wang H, Jiang J, Liu L, He S, Ding X, Liu J, Zhang Q. Targeted resequencing of GWAS loci reveals novel genetic variants for milk production traits. BMC Genomics 15,1(2014-12-15). 2014;15(1):1-9.

14. Gao H, Qi YU. Primordial follicle assembly and development. J Reprod Med. 2007;16(6):453-456.

15. Ginther OJ, Beg MA, Donadeu FX, Bergfelt DR. Mechanism of follicle deviation in monovular farm species. Anim Reprod Sci. 2003;78(3-4):239-57.

16. Austin EJ, Mihm M, Ryan MP, Williams DH, Roche JF. Effect of duration of dominance of the ovulatory follicle on onset of estrus and fertility in heifers. J Anim Sci. 1999;77(8):2219-26.

17. Scaramuzzi RJ, Baird DT, Campbell BK, Driancourt MA, Dupont J, Fortune JE, Gilchrist RB, Martin GB, McNatty KP, McNeilly AS, et al. Regulation of folliculogenesis and the determination of ovulation rate in ruminants. Reprod Fertil Dev. 2011;23(3):444-67.

18. Liu JJ, Liang AX, Campanile G, Plastow G, Zhang C, Wang Z, Salzano A, Gasparrini B, Cassandro M, Yang LG. Genome-wide association studies to identify quantitative trait loci affecting milk production traits in water buffalo. J Dairy Sci. 2018;101(1):433-44.

19. Natalia I, Bermal CR, Nascimento TAP, Braga MAF, Oliveira SRMD, Mortati DM, Braga BA, Fernando B, Roberto C. Genome-wide association study for 
Indicator traits of sexual precocity in Nellore cattle. PLoS One. 2016;11(8): e0159502.

20. Pearson TA, Manolio TA. How to interpret a genome-wide association study. Jama. 2008;299(11):1335-1344.

21. McCarthy Ml, Hirschhorn JN. Genome-wide association studies: potential next steps on a genetic journey. Hum Mol Genet. 2008;17(R2):R156-65.

22. Refsdal AO. To treat or not to treat: a proper use of hormones and antibiotics. Anim Reprod Sci. 2000;60(60-61):109-19.

23. Li Z, Ma X, Xuan J, Wang H, Yuan Z, Wu M, Liu R, Zhu C, Wei C, Zhao F. Identification of MEF2B and TRHDE gene polymorphisms related to growth traits in a new Ujumqin sheep population. PLoS One. 2016;11(7):e0159504.

24. Khaitan D, Sankpal UT, Weksler B, Meister EA, Romero IA, Couraud PO, Ningaraj SN. Role of KCNMA1 gene in breast cancer invasion and metastasis to brain. BMC Cancer 9,1(2009-07-29). 2009:9(1):258

25. Peng L, Zhang SD, Yuen HF, Mccrudden CM, Wen Q, Chan KW, Hang FK. Identification of TWIST-interacting genes in prostate cancer. Sci China Life Sci. 2017:60(4):386-96.

26. An $\mathrm{CH}$, Je EM, Yoo NJ, Lee $\mathrm{SH}$. Frameshift mutations of cadherin genes DCHS2, CDH10 and $\mathrm{CDH} 24$ genes in gastric and colorectal cancers with high microsatellite instability. Pathol Oncol Res. 2015;21(1):181-5.

27. Işık E, Beck PP, Campi I, Özon A, Alikaşifoğlu A, Gönç N, Kandemir N. Thyroid hormone resistance: a novel mutation in thyroid hormone receptor beta (THRB) gene - case report. Turk J Pediatr. 2013;55(3):322-7.

28. Rodriguez-Castelãn J, Anaya-Hernãndez A, Mendez-Tepepa M, MartinezGomez M, Castelãn F, Cuevas-Romero E. Distribution of thyroid hormone and thyrotropin receptors in reproductive tissues of adult female rabbits. Endocr Res Commun. 2016:42(1):59-70.

29. Mann T. Secretory function of the prostate, seminal vesicle and other male accessory organs of reproduction. J Reprod Fertil. 1974;37(1):179-88.

30. Barrett $P$, Ebling FJP, Schuhler S, Wilson D, Ross AW, Warner A, Jethwa P, Boelen A, Visser TJ, Ozanne DM. Hypothalamic thyroid hormone catabolism acts as a gatekeeper for the seasonal control of body weight and reproduction. Endocrinology. 2007;148(8):3608-17.

31. Christ GJ, Andersson KE, Williams K, Zhao W, D'Agostino R Jr, Kaplan J, Aboushwareb T, Yoo J, Calenda G, Davies KP, et al. Smooth-muscle-specific gene transfer with the human maxi-k channel improves erectile function and enhances sexual behavior in atherosclerotic cynomolgus monkeys. Eur Urol. 2009:56(6):1055-66.

32. Kim ES, Elbeltagy AR, Aboul-Naga AM, Rischkowsky B, Sayre B, Mwacharo $J M$, Rothschild MF. Multiple genomic signatures of selection in goats and sheep indigenous to a hot arid environment. Heredity (Edinb). 2016;116(3): 255-64.

33. Freudenberg J, Lee HS Fau, Han BG, Shin HD, Kang YM, Sung YK, Shim SC, Choi CB, Lee AT, Gregersen PK, Bae SC et al: Genome-wide association study of rheumatoid arthritis in Koreans: population-specific loci as well as overlap with European susceptibility loci. Arthritis Rheumatol. 2014;63(4): 884-893.

34. Gibbons JR, Wiltbank MC, Ginther OJ. Relationship between follicular development and the decline in the follicle-stimulating hormone surge in heifers. Biol Reprod. 1999;60(1):72-77.

35. Morfeld KA, Brown JL. Ovarian acyclicity in zoo African elephants (Loxodonta africana) is associated with high body condition scores and elevated serum insulin and leptin. Reprod Fertil Dev. 2014;28(5):640-7.

36. Watanabe Y, Takeuchi K, Onaga SH, Sato M, Tsujita M, Abe M, Natsume R, Li M, Furuichi T, Saeki M. Chondroitin sulfate N-acetylgalactosaminyltransferase-1 is required for normal cartilage development. Biochem J. 2010;432(Pt 1):47-55.

37. Shahi P, Slorach EM, Wang CY, Chou J, Lu A, Ruderisch A, Werb Z. The transcriptional repressor ZNF503/Zeppo2 promotes mammary epithelial cell proliferation and enhances cell invasion. J Biol Chem. 2015;290(6):3803-13.

38. Chang SL, Liu YC, Chen SY, Huang TH, Liu PT, Liu FC. Identification of two evolutionarily conserved $5^{\prime}$ cis-elements involved in regulating spatiotemporal expression of Nolz-1 during mouse embryogenesis. PLoS One. 2013;8(1): e54485.

39. Day FR, Hinds DA, Tung JY, Stolk L, Styrkarsdottir U, Saxena R, Bjonnes A, Broer L, Dunger DB, Halldorsson BV, et al. Causal mechanisms and balancing selection inferred from genetic associations with polycystic ovary syndrome Nat Commun. 2015;6:8464

40. Makina SO, Muchadeyi FC, van Marle-Koster E, Taylor JF, Makgahlela ML, Maiwashe A. Genome-wide scan for selection signatures in six cattle breeds in South Africa. Genet Sel Evol. 2015;47(1):92
41. Wang L, Wang Y. Molecular characterization, expression patterns and subcellular localization of Myotrophin (MTPN) gene in porcine skeletal muscle. Mol Biol Rep. 2012;39(3):2733-8.

42. Kato MV. A secreted tumor-suppressor, mac25, with activin-binding activity. Mol Med. 2000;6(2):126-35.

43. Ueno N, Ling N, Ying SY, Esch F, Shimasaki S, Guillemin R. Isolation and partial characterization of follistatin: a single-chain Mr 35,000 monomeric protein that inhibits the release of follicle-stimulating hormone. Proc Natl Acad Sci U S A. 1987:84(23):8282-6.

44. Robertson DM, Klein R, de Vos FL, Mclachlan Rl, Wettenhall RE, Hearn MT, Burger $\mathrm{HG}$, de Kretser DM. The isolation of polypeptides with FSH suppressing activity from bovine follicular fluid which are structurally different to inhibin. Biochem Biophys Res Commun. 1987;149(2):744-9.

45. Jorgez CJ, Klysik M, Jamin SP, Behringer RR, Matzuk MM. Granulosa cellspecific inactivation of follistatin causes female fertility defects. Mol Endocrinol. 2004;18(4):953-67.

46. Muttukrishna S, Tannetta D, Groome N, Sargent I. Activin and follistatin in female reproduction. Mol Cell Endocrinol. 2004;225(1-2):45-56.

47. Wandji SA, Gadsby JE, Barber JA, Hammond JM. Messeger ribonucleic acids for IGFBP-7 and connective tissue growth factor (CTGF) are inversely regulated during folliculogenesis and early luteogenesis. Endocrinology. 2000;141(7):2648-57.

48. Casey OM, Fitzpatrick R, Mcinerney JO, Morris DG, Powell R, Sreenan JM. Analysis of gene expression in the bovine corpus luteum through generation and characterisation of 960 ESTs. Biochim Biophys Acta Gene Struct Expr. 2004; 1679(1):10-7.

49. Meo GPD, Perucatti A, Schibler L, Incarnato D, Ferrara L, Cribiu EP, lannuzzi L. Thirteen type I loci from HSA4q, HSA6p, HSA7q and HSA12q were comparatively FISH-mapped in four river buffalo and sheep chromosomes. Cytogenet Genome Res. 2000;90(1-2):102-5.

50. Di MG, Perucatti A, Uboldi C, Roperto S, Incarnato D, Roperto F, Williams J, Eggen A, Ferretti L, lannuzzi L. Comparative mapping of the fragile histidine triad (FHIT) gene in cattle, river buffalo, sheep and goat by FISH and assignment to BTA22 by RH-mapping: a comparison with HSA3. Anim Genet. 2005;36(4):363-4

51. lanella $P$, Venancio $L P$, Stafuzza NB, Miziara MN, Agarwala $R$, Schäffer AA, Riggs PK, Womack JE, Amaral ME. First radiation hybrid map of the river buffalo X chromosome (BBUX) and comparison with BTAX. Anim Genet. 2010;39(2):196-200.

52. Tantia MS, Galvão SR, Caetano AR, Paola M, Miziara MN, Aravind KM, Boby M, Pardha SG, Satish K, Aparna P. A first generation whole genome RH map of the river buffalo with comparison to domestic cattle. BMC Genomics. 2008;9(1):631

53. El-Halawany $\mathrm{N}$, Abdel-Shafy $\mathrm{H}$, Shawky AEMA, Abdel-Latif MA, Al-Tohamy AFM, El-Moneim OMA. Genome-wide association study for milk production in Egyptian buffalo. Int Symp Anim Funct Gen. 2017;2017:10-6.

54. Riaz H, Dong $P$, Shahzad M, Yang L. Constitutive and follicle-stimulating hormone-induced action of somatostatin receptor-2 on regulation of apoptosis and steroidogenesis in bovine granulosa cells. J Steroid Biochem Mol Biol. 2014:141(1):150-9.

Ready to submit your research? Choose BMC and benefit from:

- fast, convenient online submission

- thorough peer review by experienced researchers in your field

- rapid publication on acceptance

- support for research data, including large and complex data types

- gold Open Access which fosters wider collaboration and increased citations

- maximum visibility for your research: over $100 \mathrm{M}$ website views per year

At $\mathrm{BMC}$, research is always in progress.

Learn more biomedcentral.com/submissions 